\title{
NOW AVAILABLE
}

\section{CHURCH HISTORY INDEX, 1981-1990 (Volume 4)}

Includes index of all articles by author, title, and subject and all book reviews by title, author index, and reviewer which were published in CHURCH HISTORY from 1981-1990

$$
275 \text { pages }
$$

$\$ 12.00$ (including postage)

A limited number of previously published volumes of the $\mathrm{CHURCH}$ HISTORY INDEX are still available at $\$ 12.00$ each including postage:

$$
\begin{aligned}
& \text { Volume 1, 1889-1961 — no longer available } \\
& \text { Volume 2, 1962-1970 - } 107 \text { pages } \\
& \text { Volume 3, 1971-1980 - } 179 \text { pages }
\end{aligned}
$$

Requests for copies, with covering remittance, should be forwarded to:

Henry W. Bowden

American Society of Church History

P.O. Box 8517

Red Bank, NJ 07701 
"... . will serve as

a model for the

fruitfulness of

promoting

conversation

between antiquity

and postmodernity."

-Elizabeth Castelli,

College of Wooster

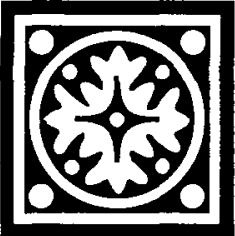

\section{DREAMS IN LATE} ANTIQUITY

Studies in the Imagination of a Culture PATRICIA COX MILLER

Dream interpretation was a prominent feature of the intellectual and imaginative world of late antiquity, for martyrs and magicians, philosophers and theologians, polytheists and monotheists alike. Finding it difficult to account for the prevalence of dream-divination, modern scholarship has often condemned it as a cultural weakness, a mass lapse into mere superstition.

In this book, Patricia Cox Miller draws on pagan, Jewish, and Christian sources and modern semiotic theory to demonstrate the integral importance of dreams in late-antique thought and life. She argues that Graeco-Roman dream literature functioned as a language of signs that formed a personal and cultural pattern of imagination and gave tangible substance to ideas such as time, cosmic history, and the self.

Cloth: $\$ 39.50$ ISBN 0-691-07422-4

\section{PRINCETON UNIVERSITY PRESS}

\section{FACULTY POSITION CHURCH HISTORY}

ouisville Presbyterian Theological Seminary is seeking a faculty member in church history since the Reformation. Applicants should have a Ph.D.

Applications from women and racial/ethnic candidates are especially encouraged.

This person will have the opportunity to teach students enrolled in M.Div., M.A., Th.M., and D.Min. degree programs. Candidates should have a strong interest in preparing people for the Christian ministry.

Rank and tenure are negotiable on the basis of experience; appointment will begin in the fall of 1985.

Louisville Seminary follows E.E.O. guidelines and affirmative action procedures. Send dossiers and a list of at least three references to:

President John Mulder, 1044 Alta Vista Road

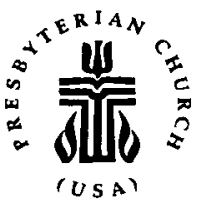




\section{CA LVI N}

College

"HIDDEN TREASUIRES IN JOHN CALVIN"

By Dr. Heiko A. Oberman, Professor, University of Arizona Director of Late Medieval and Reformation Studies.

Dates: Friday, October 28, 1994

Saturday, October 29, 1994

Location: Calvin College Commons Lecture Hall

Sponsored by the H. Henry Meeter Center for Calvin Studies, Calvin College and Calvin Theological Seminary

In celebration of Reformation Day (Sunday, October 30), the H. Henry Meeter Center will sponsor two exciting lectures by Dr. Heiko A. Oberman. Please join us for a weekend lecture series that is certain to be stimulating, informative, and entertaining.

For further information, please write to:

H. Henry Meeter Center for Calvin Studies, Atm: Oberman Conference

3201 Burton Street SE, Grand Rapids, MI 49546 


\section{AMERICAN SOCIETY OF CHURCH HISTORY \\ Membership Information}

The American Society of Church History was founded in 1888 by Philip Schaff and a group of colleagues. It is affiliated with the American Historical Association. Its purpose is to foster interest in the history of Christianity, and its interrelationship with its cultural context by encouraging research, writing, and teaching in this discipline.

The membership of the society consists of scholars, men and women, the majority of whom serve on faculties of colleges, universities, and seminaries. Others are archivists, clergy members, professional writers, and students, or simply those who have a serious interest in church history. The society is ecumenical in character, comprising members of various religious persuasions.

In addition to Church History, a journal published quarterly, the society holds an annual meeting in conjunction with the American Historical Association and a spring meeting on the campus of a host institution. The meeting programs and the journal provide opportunities for exploring a wide variety of subjects and the exchange of thought. Membership dues entitle one to receive the journal, with its informative articles and large book review section, and attend the meetings of the society.

In order to interest younger scholars, particularly those of ethnic minorities, in the work of the society, the council has voted to offer a dues-free membership (up to two years) to all graduate students working in the area of church history at an accredited institution upon the approval of a professor who is also a member of the society.

Application for Membership

American Society of Church History

Name: last first $\quad$ middle

\begin{tabular}{lllll}
\hline Address: & street & city & state & zip
\end{tabular}

Present institutional affiliation/Last degree earned-when and where

Signature

Professor's signature (If graduate student)

Annual dues are $\$ 30.00$, plus $\$ 7.00$ foreign postage, including Canada. Graduate students working in the area of church history with the approval and verification of a professor who is also a member of the society may join without paying a fee. Persons who have been members of the society for at least five years and are now retired from professional life may continue membership at $\$ 15.00$ per year. Membership in the society includes a subscription to Church History. The council approves applications at its semiannual meetings.

Send to: Henry W. Bowden, P.O. Box 8517, Red Bank, NJ 07701. 


\section{PRIZES OF THE AMERICAN SOCIETY OF CHURCH HISTORY}

\section{The Frank S. and Elizabeth D. Brewer Prize}

The Frank S. and Elizabeth D. Brewer Prize, offered annually, is a subvention fund of $\$ 1000$ to assist a press in publishing a book-length manuscript in church history. The Brewer Prize is limited to first books. Manuscripts already accepted for publication may be submitted for this award, but the publication must have printed on its title-page, "The Frank S. and Elizabeth D. Brewer Prize Essay of the American Society of Church History." The monetary grant will be authorized upon receipt in writing of a commitment from a publisher accepting the manuscript. Complete manuscripts in final form must be received by Henry W. Bowden, P.O. Box 8517, Red Bank, NJ 07701, by 1 November. Manuscripts may not be submitted in more than one ASCH competition. The award will be announced at the Spring meeting of the Society. No award will be made in any year when none of the manuscripts is adjudged to be outstanding.

Winner for 1994: Stephen Burnett "From the Jews' Own Books: Johann Buxtorf, Christian Hebraism, and the Emergence of Jewish Studies."

Winner for 1993: Diana Hochstedt Butler, "Standing Against the Whirlwind: A Study of the Evangelical Party in the Protestant Episcopal Church."

Winner for 1992: Gregory Hanlon, "Confession and Community in SeventeenthCentury France: Catholics and Protestants in Acquitaine."

\section{The Philip Schaff Prize}

The Philip Schaff Prize is an award in the amount of $\$ 1000$ to be paid to the author of the best book originating in the North American scholarly community which presents original research in the history of Christianity or any period thereof. This award is given in odd-numbered years. Books published during the two previous calendar years are eligible for the competition. Any member of the Society may nominate titles for consideration. Copies of nominated books need not be submitted. Titles of nominated books must be received by Henry W. Bowden, P.O. Box 8517, Red Bank, NJ 07701 by 1 March in odd-numbered years. The prize will be announced at the annual Winter meeting of the Society.

Winner for 1993: Stephen J. Stein, The Shaker Experience in America.

Winner for 1991: David D. Hall, Worlds of Wonder, Days of Judgment: Popular Religious Belief in Early New England.

\section{The Sidney E. Mead Prize}

The Sidney E. Mead Prize is an award in the amount of $\$ 250$ for the author of the best unpublished essay in any field of church history written by a doctoral candidate or recent recipient whose manuscript stems directly from doctoral research. The manuscript will be published in Church History. Entries of no more than twenty-five double-spaced pages, including double-spaced endnotes, must be submitted to Henry W. Bowden, P.O. Box 8517, Red Bank, NJ 07701, by 1 July. The prize is offered annually, though no award will be made in any year when none of the manuscripts is adjudged to be outstanding. Manuscripts may not be submitted in more than one ASCH competition. The winner will be announced at the annual Winter meeting of the Society.

Winner for 1992: Alison Williams Lewin, "Cum Status Ecclesie Noster Sit . . .' Florence and the Council of Pisa (1409)."

Winner for 1991: Ernest Freeburg, " 'An Object of Peculiar Interest': The Education of Laura Bridgman." 


\section{THE ALBERT C. OUTLER PRIZE IN ECUMENICAL CHURCH HISTORY}

The Albert C. Outler Prize in Ecumenical Church History consists of an award of $\$ 1000$ to the author of a book-length manuscript and a possible grant of up to $\$ 3000$ for publication costs-or in exceptional cases, for necessary expenses in the preparation of a manuscript accepted for publication. The term "Ecumenical" is to be construed as chiefly concerned with the problems of Christian unity and disunity (doctrinal, cultural, institutional) in any period of church history, or with interactions between Christianity and other religious movements. Works of a partisan nature are excluded. The winning manuscript must have printed on its title-page, "The Albert C. Outler Prize in Ecumenical History of the American Society of Church History." Complete manuscripts in final form must be received by Henry $W$. Bowden, P.O. Box 8517, Red Bank, NJ 07701, by 1 June. The prize is offered annually, though no award will be made in any year when none of the manuscripts is adjudged to be outstanding. Manuscripts may not be submitted in more than one ASCH competition. The winner will be announced at the annual Winter meeting of the Society.

Winner 1993: Allen C. Guelzo, For the Union of Evangelical Christendom: The Irony of the Reformed Episcopalians, 1873-1930.

Winner for 1991: Ronald L. Numbers, The Creationists.

\section{THE JANE DEMPSEY DOUGLASS PRIZE}

The Jane Dempsey Douglass Prize is an award in the amount of $\$ 250$ for the author of the best unpublished essay on some aspect of the role of women in the history of Christianity. The manuscript will be published in Church History. Entries of no more than twenty-five double-spaced pages, including doubled-spaced endnotes, must be submitted to Henry W. Bowden, P.O. Box 8517, Red Bank, NJ 07701, by 1 August each year. The prize is offered annually, though no award will be made in any year when none of the manuscripts is adjudged to be outstanding. Manuscripts may not be submitted in more than one ASCH competition. The winner will be announced at the annual Winter meeting of the Society.

Winner for 1993: Genevieve McCoy, "Post-Edwardian Calvinism and the Women of the ABCFM Oregon Mission."

Winner for 1991: Joyce Irwin, "Pietism and Women: A Study in Contrasts." 


\title{
PLAN AHEAD
}

\author{
Spring Meeting \\ 20-22 April 1995 \\ University of Miami, Miami Florida
}

Proposals for papers, sessions, moderators, and respondents are welcomed by the Program Committee. Send all suggestions and offers to:

Professor Daniel L. Pals

Department of Religious Studies

P.O. Box 248265

Coral Gables, FL 33124

\section{PLAN AHEAD}

\author{
Winter Meeting \\ 5-8 January 1995 \\ Chicago, Illinois
}

Proposals for papers, sessions, moderators, and respondents are welcomed by the Program Committee. Send all suggestions and offers to:

\author{
Professor Stephen J. Stein \\ 1420 E. Maxwell Lane \\ Bloomington, IN 47401
}

